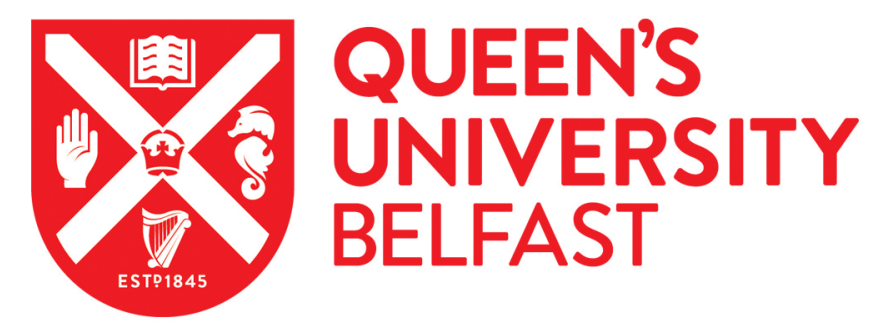

\title{
Preliminary Investigation on the Electrochemical Activity of Butanol Isomers as Potential Fuel for Direct Alcohol Fuel Cell
}

Puthiyapura, V. K., Brett, D. J., Russell, A. E., Lin, W. F., \& Hardacre, C. (2015). Preliminary Investigation on the Electrochemical Activity of Butanol Isomers as Potential Fuel for Direct Alcohol Fuel Cell. ECS Transactions, 69 (17), 809-816. https://doi.org/10.1149/06917.0809ecst

\section{Published in: \\ ECS Transactions}

\section{Document Version:}

Peer reviewed version

Queen's University Belfast - Research Portal:

Link to publication record in Queen's University Belfast Research Portal

Publisher rights

(C) 2015 ECS - The Electrochemical Society

\section{General rights}

Copyright for the publications made accessible via the Queen's University Belfast Research Portal is retained by the author(s) and / or other copyright owners and it is a condition of accessing these publications that users recognise and abide by the legal requirements associated with these rights.

Take down policy

The Research Portal is Queen's institutional repository that provides access to Queen's research output. Every effort has been made to ensure that content in the Research Portal does not infringe any person's rights, or applicable UK laws. If you discover content in the Research Portal that you believe breaches copyright or violates any law, please contact openaccess@qub.ac.uk. 


\title{
Preliminary Investigation on the Electrochemical Activity of Butanol Isomers as Potential Fuel for Direct Alcohol Fuel Cell
}

\author{
V. K. Puthiyapura ${ }^{\mathrm{a}}$, D. J. Brett ${ }^{\mathrm{b}}$, A E. Russell ${ }^{\mathrm{c}}$, W. F. Lin ${ }^{\mathrm{a}^{*}}$, and C. Hardacre $\mathrm{a}^{\mathrm{a}^{*}}$ \\ aSchool of Chemistry and Chemical Engineering, Queen's University Belfast, Belfast, \\ BT9 5AG, UK \\ ${ }^{\mathrm{b}}$ Department of Chemical Engineering, University College London, London WC1E 7JE, \\ UK \\ ${ }^{\mathrm{c}}$ Department of Chemistry, University of Southampton, High field, Southampton SO17
}

1BJ, UK

\begin{abstract}
A preliminary investigation of electrocatalytic oxidation activity of butanol isomers has been carried out to study their potential as fuels for direct alcohol fuel cells. The electrochemical study was carried out on Pt and Pd electrodes using a three electrode cell set up in alkaline media. The primary alcohol isomers of butanol were observed to behave similarly in their electrochemical reactions whereas 2-butanol showed completely different oxidation features on both catalysts. For example, no poisoning effects were observed for 2- butanol unlike for the primary butanol isomers. In contrast, tert-butanol did not show any oxidation reaction on $\mathrm{Pt}$ and $\mathrm{Pd}$ electrodes. Furthermore, Pd was not active at all in acidic media for butanol oxidation. The reactivity of butanol isomers were found to be in the order $n$-butanol>iso-butanol>2-butanol>tert-butanol based on the oxidation current density values.
\end{abstract}

\section{Introduction}

Low molecular weight alcohols, such as methanol and ethanol, have been proposed as promising alternative fuels to $\mathrm{H}_{2}$ in low temperature fuel cells due to their liquid nature, high energy density, low toxicity, availability and ease of handling (1-3). Methanol and ethanol are widely studied as fuels for direct alcohol fuel cells (DAFCs) (3). However, methanol is toxic and is not a primary fuel or renewable fuel; thus it is not considered as suitable for practical DAFCs, whereas ethanol is non-toxic and can be produced by fermentation of sugars. Bio-ethanol is mainly produced by the fermentation of sugar containing material (starch and sugar based stocks such as sugar cane, corn etc.) by yeast (4). Bio-ethanol is now widely used as a gasoline additive, with the objective to reduce the fossil fuel content in the automobile fuel. However, the use of $1^{\text {st }}$ generation bio-fuels (produced from food based biomass feed stock) such as bioethanol and bio-diesel has been strongly debated with respect to the ethics of utilising food stocks for fuel production, instead of as a food source (5). An alternate renewable source, which does not compete with the food, is required for a sustainable energy future. Thus, $2^{\text {nd }}$ generation bio-fuels are proposed to be produced from non-food based biomass, such as lignocellulose biomass (LCB) feed-stock (eg: corn stover and fiber, wheat and barley straw, switch grass, miscanthus) $(4,5)$. The advantage of cellulose and lignin based feedstocks are that they are abundant and can be considered as waste products. 
Butanol $(\mathrm{BtOH})$ is considered as a $2^{\text {nd }}$ generation bio-fuel, with better infrastructure compatibility than ethanol and is superior to ethanol as a fuel itself or as a gasoline additive. $\mathrm{C}_{4}$ alcohols have a higher energy content, lower water adsorption, and better blending ability than ethanol and are considered as potential substitute for gasoline as an automobile fuel (4-6) In addition, bio-butanol is non-toxic, non-corrosive, easily biodegradable and thus does not lead to soil and water pollution (7). This renewed interest in bio-butanol as a sustainable vehicle fuel has led technological advances which helped in the formulation of a cost effective method for bio-butanol production. The first commercial-scale facilities are expected to be former ethanol corn plants converted to bio-butanol corn plants (6). Multiple companies are now working on the development of commercial scale bio-butanol production; for example, GreenBiologics, (UK) produce pure $n$-BtOH under the trade name ButaChem ${ }^{\mathrm{TM}}$ (8); Cobalt Technology, (USA) developed cost effective method to produce $n$-BtOH by a biological process from LCB feedstock (residual forestry and agricultural crops) (9) ; $\operatorname{Butamax}^{\mathrm{TM}}$, a joint venture between BP and DuPont, has the technology to produce bio-butanol (iso-butanol) from food stock biomass (corn, wheat, sugarcane, molasses) $(10,11)$ and are planning to develop biocatalyst for butanol production from LCB as well (10); Vivergo Fuel, a joint venture between DuPont and AB Sugar are planning to convert their bio-ethanol plant gradually to bio-butanol production with the development of the Butamax technology (4, 12, 13); Gevo, (USA) uses a biocatalyst for the production of iso-butanol from fermentable sugars and are developing bio-catalyst for the fermentation of LCB (14).

Although there are a significant number of studies examining small-chain alcohols, such as methanol and ethanol, there are far fewer studies on longer-chain alcohols such as butanol. On complete electro-oxidation, butanol can provide $24 \mathrm{e}^{-}$per molecule, compared with $12 \mathrm{e}^{-}$and $6 \mathrm{e}^{-}$for ethanol and methanol, respectively. However, increasing the alkyl chain length will increase the number of possible intermediates and complicate the reaction pathway. Butanol also has an advantage over short chain length alcohols in that the fuel crossover through the electrolyte membrane, which is one of the major issues in DAFCs, will be reduced. In this study, a preliminary investigation has been carried out to study the electrochemical activity of butanol isomers in alkaline media on $\mathrm{Pt}$ and $\mathrm{Pd}$ electrodes.

\section{Experimental}

Electrodeposition onto glassy carbon (GC) electrodes (Goodfellow, UK) was carried out using a conventional three-electrode cell with $\mathrm{Ag} / \mathrm{AgCl}-3 \mathrm{M} \mathrm{NaCl}$ (BaSi, USA) $(0.210$ $\mathrm{V}$ vs. SHE) as the reference electrode and Pt mesh (Goodfellow, UK) as the counter electrode. All potentials are referenced with respect to $\mathrm{Ag} / \mathrm{AgCl}-3 \mathrm{M} \mathrm{NaCl}$ unless specified otherwise. The Pt was deposited on $\mathrm{GC}$ from $5 \mathrm{~mm} \mathrm{H}_{2} \mathrm{PtCl}_{6}+0.5 \mathrm{M} \mathrm{H}_{2} \mathrm{SO}_{4}$ solution at a deposition potential of $-0.22 \mathrm{~V}$. The $\mathrm{Pd}$ electrodes were prepared by electrodeposition on $\mathrm{GC}$ electrodes from $5 \mathrm{mM} \mathrm{Pd}$ sulphate+0.5 $\mathrm{M} \mathrm{H}_{2} \mathrm{SO}_{4}$ solution at deposition potential of $-0.20 \mathrm{~V}$. The cyclic voltammogram $(\mathrm{CV})$ analyses were carried out in nitrogen-saturated $0.1 \mathrm{M}$ butanol isomer $+0.1 \mathrm{M} \mathrm{NaOH}$. The electrochemical surface area (ESA) of Pt was calculated from the CV in sulphuric acid (SA). The current values were normalized to the ESA of Pt and Pd. 


\section{Result and Discussion}

$\underline{\text { Butanol Isomers in Acidic Media }}$

In this work, different butanol isomers were tested for their reactivity towards electrooxidation in alkaline media over Pt and Pd catalysts. The Pt deposited on GC was confirmed from the $\mathrm{CV}$ in $0.1 \mathrm{M} \mathrm{H}_{2} \mathrm{SO}_{4}$ (Figure $3 \mathrm{a}$ ) and the $\mathrm{CV}$ was also used to calculate the electrochemical active surface area (ESA) of Pt using equation [1] where $Q_{\mathrm{H}}$ is the charge for hydrogen desorption and $Q_{\mathrm{H}}{ }^{\mathrm{O}}$ is the charge required to oxidize a monolayer of hydrogen from Pt surface $\left(0.21 \mathrm{mC} \mathrm{cm}^{-2}\right)$.

$$
\mathrm{ESA}=Q_{\mathrm{H}} / Q_{\mathrm{H}^{\circ}}
$$

The CVs of electro-oxidation of the four butanol isomers used on $\mathrm{Pt}$ in alkaline media at room temperature are compared in Figure 1 . Both $n-\mathrm{BtOH}$ and iso- $\mathrm{BtOH}$ (primary alcohols) showed similar CVs whereas 2-butanol showed a significantly different profile. In contrast, tert-BtOH, did not show any oxidation activity. Both $n-\mathrm{BtOH}$ and iso-BtOH showed two oxidation peaks during positive going potential scan (PGPS) $(\sim-0.05 \mathrm{~V}$ and $0.25 \mathrm{~V})$ and one oxidation peak during negative going potential scan (NGPS) $(-0.40 \mathrm{~V})$.

The features of $\mathrm{Pt}$ in alkaline media within the hydrogen adsorption/desorption region were not present in the $\mathrm{CV}$ of $n-\mathrm{BtOH}$ and $i s o-\mathrm{BtOH}$ indicating that a large proportion of the Pt surface active sites were covered by butanol or other butanol related adsorbates. The oxidation starts to increase after the hydrogen desorption potential, giving a peak at $0.10 \mathrm{~V}-0.00 \mathrm{~V}$ region. During the NGPS, an anodic peak appears $\sim-0.40 \mathrm{~V}$. It has been reported that the first step of the primary alcohol oxidation reaction is the $\mathrm{C}-\mathrm{H}$ activation at the $\alpha-\mathrm{C}$ of the alcohol molecule $(15,16)$. This is thought to occur at low potential, leading to the dissociative adsorption of the alcohol molecule and forming $\mathrm{CO}$ which blocks the Pt active sites and hinders further adsorption of the alcohol molecule. In acidic media, water oxidation on $\mathrm{Pt}$ at high potential forms $\mathrm{OH}_{\text {ads }}$ which helps in the removal of $\mathrm{CO}_{\text {ads }}$ as $\mathrm{CO}_{2}$ (Equation 1) making the $\mathrm{Pt}$ active sites available for further adsorption/oxidation of alcohol (Figure 3a). In alkaline media, the $\mathrm{OH}$ adsorption occur at significantly lower potential and thus the reaction (Equation 1) occur just after the hydrogen desorption region, giving the first anodic peak.

$$
\mathrm{Pt}-\mathrm{CO}_{\mathrm{ads}}+\mathrm{Pt}-\mathrm{OH}_{\mathrm{ads}} \rightarrow \mathrm{CO}_{2}+\mathrm{Pt}+\mathrm{H}^{+}+\mathrm{e}^{-}
$$

The onset potential for the oxidation current was at $\sim-0.50 \mathrm{~V}$ for both $n-\mathrm{BtOH}$ and $i s o$ $\mathrm{BtOH}$. The presence of $\mathrm{OH}^{-}$in the solution and on the surface of the catalyst could also catalyse the initial de-protonation of alcohol. In contrast to the primary isomers, 2-BtOH showed a significant oxidation current even before the complete desorption of hydrogen (Figure 1c), giving a peak at $\sim-0.52 \mathrm{~V}$. However, the current density observed for 2butanol was lower than that on $n-\mathrm{BtOH}$ and $i s o-\mathrm{BtOH}$. During the NGPS, an anodic peak 
was observed at $\sim-0.50 \mathrm{~V}$. It is clear that, the secondary alcohol has a different oxidation mechanism compared with the primary alcohols. The hydrogen desorption region were not suppressed to the same degree, as found for $n-\mathrm{BtOH}$ and iso-BtOH which confirms that the dissociative adsorption (C-C bond breaking) to form strongly adsorbed intermediates such as CO does not occur for 2-butanol $(17,18)$. Therefore, the direct oxidation of 2-butanol occurs once the hydrogen is desorbed from the Pt surface. An absence of $\mathrm{CO}_{\text {ads }}$ during secondary alcohol oxidation has been reported previously for 2propanol based on FT-IR studies (19). During the NGPS, the reduction of $\mathrm{PtO}_{\mathrm{x}}$ makes the Pt actives sites free of adsorbed species (oxides, hydroxides, adsorbed organic species) leading to the adsorption and oxidation of fresh butanol giving an oxidation peak at similar potential region as found in the case of $n-\mathrm{BtOH}$ and $i s o-\mathrm{BtOH}$. From the current density values it is clear that the oxidation activity follows the order $n$-butanol >isobutanol > 2-butanol > tert-butanol $(15,20)$.

Tert-BtOH did not show any oxidation activity and the $\mathrm{CV}$ showed features that were similar to those of $\mathrm{Pt}$ in acid at room temperature (Figure $1 \mathrm{~d}$ ) with lower current densities compared with other isomers. The lower activity of tert-BtOH is not surprising as no $\alpha \mathrm{C}-\mathrm{H}$ bonds are present which is the first step in the oxidation of the alcohol molecule.
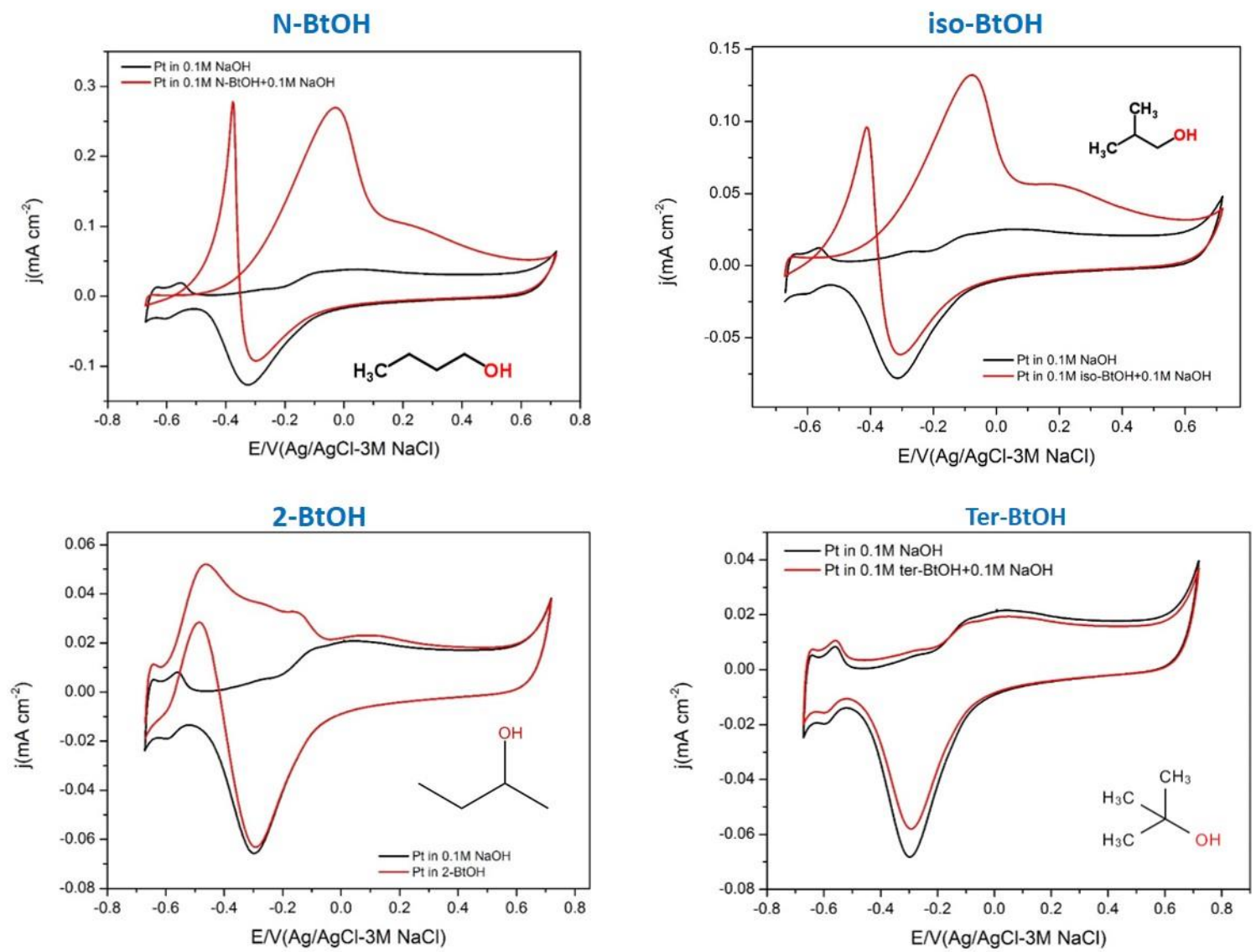

Figure 1. CV of butanol isomers on $\mathrm{Pt}$ in alkaline media. (a) $0.1 \mathrm{M} n-\mathrm{BtOH}+0.1 \mathrm{M} \mathrm{NaOH}$ (b) $0.1 \mathrm{M}$ iso-BtOH+0.1 M NaOH (c) $0.1 \mathrm{M} 2-\mathrm{BtOH}+0.1 \mathrm{M} \mathrm{NaOH}$ (d) $0.1 \mathrm{M}$ tert$\mathrm{BtOH}+0.1 \mathrm{M} \mathrm{NaOH}$. Scan rate $50 \mathrm{mVs}^{-1}$. The $\mathrm{CV}$ of $\mathrm{Pt}$ in the supporting electrolyte is also given. 
The trend in the activity could be attributed to the inductive effect among the butanol isomers as the proton removal from $\alpha \mathrm{C}-\mathrm{H}$ is the first step in the oxidation of alcohol. The partial positive charge of the $\alpha \mathrm{C}$ decrease in the order $n$-butanol $>$ iso-butanol > 2-butanol $>$ tert-butanol which makes the removal of $\mathrm{H}$ from $\mathrm{C}-\mathrm{H}$ difficult (15).

\section{$\underline{\text { Pd Electrode in Alkaline Media }}$}

The Pd electrode was tested in both acid and alkaline electrolytes and is compared in Figure 2.

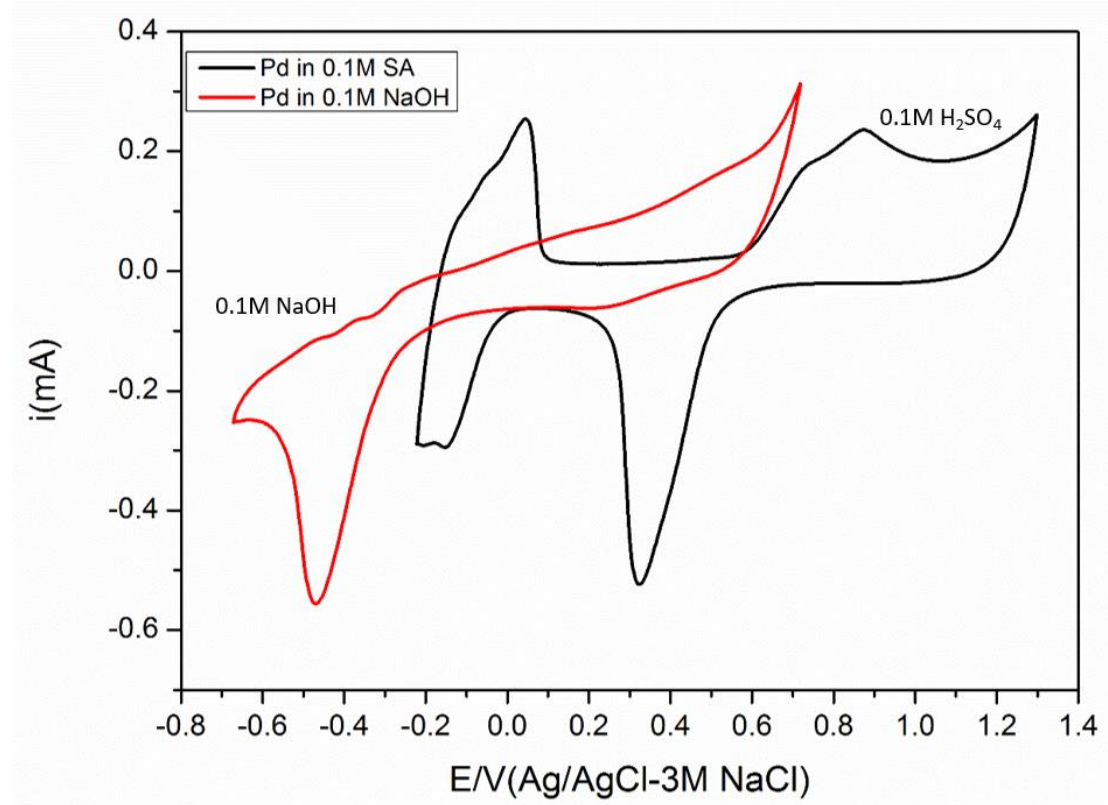

Figure 2. The CV of Pd electrode in $0.1 \mathrm{M} \mathrm{H}_{2} \mathrm{SO}_{4}$ and $0.1 \mathrm{M} \mathrm{NaOH}$ electrolytes. Scan rate $50 \mathrm{mVs}^{-1}$.

Unlike Pt electrodes, the ESA calculation for Pd is difficult from the monolayer hydrogen charge due to the ability of bulk Pd to absorb hydrogen $(21,22)$. Thus the ESA was calculated from the charge of monolayer of chemisorbed oxygen $\left(Q_{0}\right)$ which in turn calculated from the PdO reduction peak area (23) using equation [2] where QPdo is the charge required for the reduction of Pd-O monolayer $\left(405 \mu \mathrm{C} \mathrm{cm}^{-2}\right)(22,24,25)$.

$$
\mathrm{ESA}=\mathrm{Q}_{0} / \mathrm{QPdO}
$$



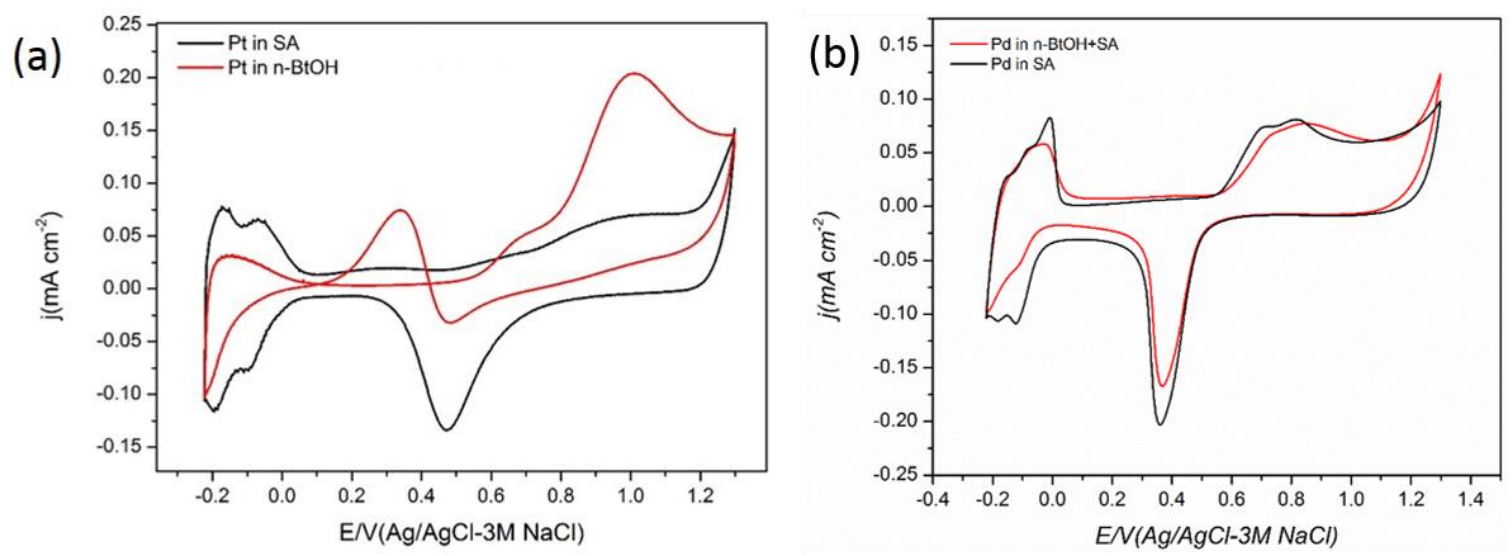

Figure 3. The CV of (a) Pt electrode in $0.1 \mathrm{M} \mathrm{H}_{2} \mathrm{SO}_{4}$ and $0.1 \mathrm{M} n-\mathrm{BtOH}+0.1 \mathrm{M} \mathrm{H}_{2} \mathrm{SO}_{4}$ and (b) Pd electrode in $0.1 \mathrm{M} \mathrm{H}_{2} \mathrm{SO}_{4}$ and $0.1 \mathrm{M} \mathrm{H}_{2} \mathrm{SO}_{4}+n$-butanol.

The Pd electrode was tested in $n$ - $\mathrm{BtOH}$ containing acidic solution and the $\mathrm{CV}$ feature were virtually the same as that of the supporting electrolyte media indicating that $\mathrm{Pd}$ is not active in acidic media whereas $\mathrm{Pt}$ was active for $n$-BtOH oxidation in acidic media (Figure 3). However in alkaline media, the Pd electrode was active with similar trends observed as those found for Pt (Figure 4). Under these conditions, both $n$ - $\mathrm{BtOH}$ and iso$\mathrm{BtOH}$ showed similar $\mathrm{CV}$ features with one anodic peak between at $0.00-0.05 \mathrm{~V}$ during the PGPS and one anodic peak at $-0.45--0.40 \mathrm{~V}$ during NGPS. The 2-butanol oxidation current starts to increase at a lower potential of $\sim-0.60 \mathrm{~V}$ and multiple oxidation peaks are observed up to a potential of $0.00 \mathrm{~V}$. As found under acidic conditions over Pt, tert$\mathrm{BtOH}$ was not reactive at all. The reactivities were in the order of $n$-butanol $>i s o$-butanol $>$ 2-butanol > tert-butanol based on the current density values. The current density associated with the Pd electrode under alkaline conditions was significantly higher compared with $\mathrm{Pt}$ in acidic media although it should be noted that the ESA was calculated differently in each case which may influence the results. It is clear that, the alkaline media is more favourable and Pd is the most active catalyst in alkaline media although it is not active under acid conditions. The Pt on the other hand is active in both acidic and alkaline media, albeit it was not as active as Pd in alkaline media. 

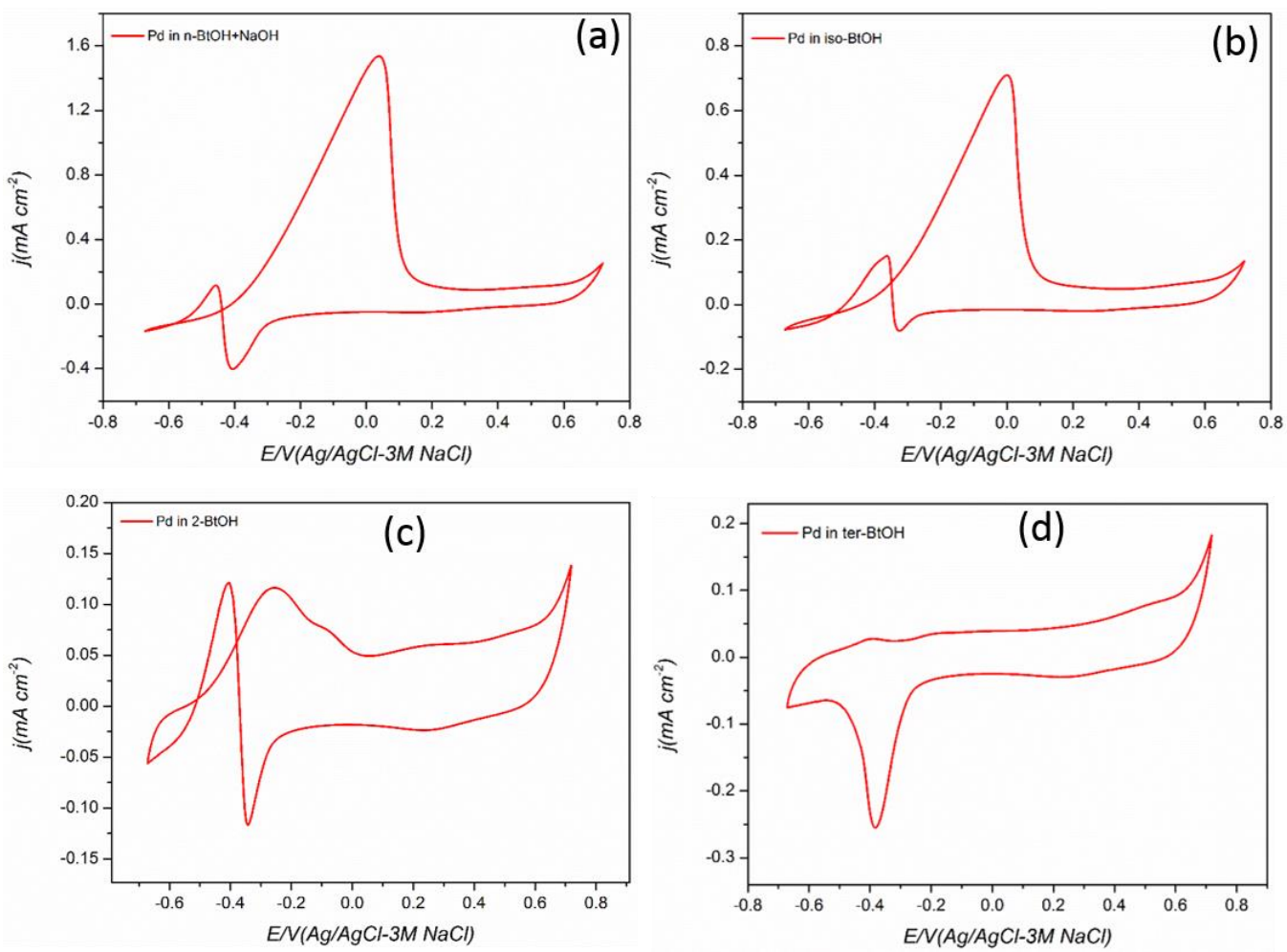

Figure 4. The $\mathrm{CV}$ of Pd electrode in $0.1 \mathrm{M}$ butanol isomer+ $+0.1 \mathrm{M} \mathrm{NaOH}$ solution. (a) $n$ butanol (b) iso-butanol (c) 2-butanol (d) tert-butanol. Scan rate $50 \mathrm{mVs}^{-1}$.

\section{Conclusions}

Butanol isomers were studied as potential fuels for DAFCs in a three-electrode setup in alkaline media on Pt and Pd electrodes. The primary alcohol isomers, $n$-butanol and iso-butanol showed similar CV characteristics where the oxidation profile of 2-butanol was significantly different. On $\mathrm{Pt}$, both the primary isomers showed two anodic peaks during PGPS and one anodic peak during NGPS, respectively. The onset potential of oxidation of the primary isomers was at the region where $\mathrm{PtO}_{\mathrm{x}}$ is formed indicating the effect of $\mathrm{OH}_{\text {ads }}$ on their oxidation. It is clear that a poisoning species, presumed to be $\mathrm{CO}$, is being removed with the help of $\mathrm{OH}_{\mathrm{ads}}$ on Pt. In the case of 2-butanol, the oxidation started just after the hydrogen desorption region indicating that $\mathrm{CO}$ poisoning did not occur, which indicates that no $\mathrm{C}-\mathrm{C}$ bond breaking was evident on alcohol adsorption. Oxidation of the secondary isomer thus follows a different mechanism in comparison to the primary isomers. Tert-butanol did not show any oxidation activity in alkaline media on both Pt and Pd electrodes. The activities of butanol isomers were in the order of $n$ butanol>iso-butanol>2-butanol>tert-butanol on both Pt and Pd based on the oxidation current density values. However, the current density values were higher on Pd than on $\mathrm{Pt}$ in alkaline media. Pd did not show any activity for butanol oxidation in acidic media whereas Pt was active towards butanol oxidation in both acidic and alkaline media. It is clear that primary isomers are most reactive for oxidation in alkaline media on $\mathrm{Pt}$ and $\mathrm{Pd}$ electrodes and thus they represent potential fuels for DAFCs considering also their production from bio-mass feed stocks. 


\section{Acknowledgments}

Author acknowledges the financial support from the Engineering and Physical Sciences Research Council (EPSRC), UK (Grant number EP/K014706/1) and the UK Catalysis Hub.

\section{References}

1. C. Lamy, E. M. Belgsir and J. M. Léger, J. Appl. Electrochem., 31, 799 (2001).

2. A. Brouzgou, F. Tzorbatzoglou and P. Tsiakaras, in Energetics (IYCE), Proceedings of the 2011 3rd International Youth Conference on, p. 1 (2011).

3. C. Lamy, A. Lima, V. LeRhun, F. Delime, C. Coutanceau and J.-M. Léger, J. Power Sources, 105, 283 (2002).

4. L. Tao, X. He, E. C. D. Tan, M. Zhang and A. Aden, Biofuels, Bioprod. Biorefin., 8, 342 (2014).

5. P. Dürre, Biotechnol. J., 2, 1525 (2007).

6. A. F. D. Center, Biobutanol, http://www.afdc.energy.gov/fuels/emerging biobutanol.html.

7. P. Patakova, D. Maxa, M. Rychtera, M. Linhova, P. Fribert, Z. Muzikova, J. Lipovsky, L. Paulova, M. Pospisil and G. S. a. K. Melzoch, in Biofuel's Engineering Process Technology, M. A. D. S. Bernardes Editor, InTech (2011).

8. S. Mukerjee and J. McBreen, J. Electrochem. Soc., 146, 600 (1999).

9. Cobalt Technologies, http://www.cobalttech.com/technology.html.

10. L. Butamax ${ }^{\mathrm{TM}}$ Advanced Biofuels, BP and DuPont, California Biobutanol Multimedia Evaluation- Tier I Report, in (2010).

11. J. L. Zubimendi, L. Vazquez, P. Ocon, J. M. Vara, W. E. Triaca, R. C. Salvarezza and A. J. Arvia, J. Phys. Chem., 97, 5095 (1993).

12. K. Scott, I. Cotlarciuc, D. Hall, J. B. Lakeman and D. Browning, J. Appl. Electrochem., 38, 1313 (2008).

13. K. Scott, I. Cotlarciuc, I. Head, K. P. Katuri, D. Hall, J. B. Lakeman and D. Browning, J. Chem. Technol. Biotechnol., 83, 1244 (2008).

14. Gevo, Iso-butanol, http://www.gevo.com/about/our-business/our-science-andtechnology/.

15. D. Takky, B. Beden, J.-M. Leger and C. Lamy, J. Electroanal. Chem., 193, 159 (1985).

16. B. Habibi and E. Dadashpour, Electrochim. Acta, 88, 157 (2013).

17. G. S.Lj., T. A.V. and S. R.M, J. Serb. Chem. Soc., 72, 1419 (2007).

18. C.-G. Lee, M. Umeda and I. Uchida, J. Power Sources, 160, 78 (2006).

19. E. Pastor, S. González and A. J. Arvia, J. Electroanal. Chem., 395, 233 (1995).

20. D. Takky, B. Beden, J. M. Leger and C. Lamy, J. Electroanal. Chem., 145, 461 (1983).

21. M. W. Breiter, J. Electroanal. Chem., 81, 275 (1977).

22. P. Mukherjee and S. Bhattacharya, J. Appl. Electrochem., 44, 857 (2014).

23. G. F. Álvarez, M. Mamlouk and K. Scott, Int.J. Electrochem., 2011, 12 (2011).

24. R. N. Singh, A. Singh and Anindita, Int. J. Hydrogen Energy, 34, 2052 (2009).

25. S. S. Mahapatra and J. Datta, Int.J. Electrochem., 2011, 16 (2011). 